\title{
Habitat Studies Identifying Potential Trees for Urban Paved Environments: A Case Study from Qinling Mt., China
}

\author{
Henrik Sjöman, Anders Busse Nielsen, Stephan Pauleit, and Mats Olsson
}

\begin{abstract}
Trees in urban paved environments are highly exposed to heat, low air humidity, periods of critical water stress, high soil lime content and soil $\mathrm{pH}$, limited soil volume, pollutants, and de-icing salts. Combined with the challenges of climate change and the threat of disease and pest infestations, this has led to considerable and persistent arguments for using a more varied range of trees, including stress-tolerant species, at urban paved sites. Extensive fieldwork was carried out in the Qinling Mountains, China, in a search for tree species suitable for urban paved sites in northern parts of central Europe and in adjoining milder parts of northern Europe (CNE-region), where tree species are exposed to seasonally dry and harsh conditions. The study identified habitats in the Qinling Mountain range that are similar to those at sites in paved environments, and analyzed the growth and performance of different tree species in these habitats. A total of 25 tree species representing 21 genera were found, of which 14 species were identified as specialist colonizers of warm, dry south-facing slopes where site conditions are similar to those in paved environments of the CNE-region.

Key Words: Habitat Studies; Selection; Site-Adapted Species Use; Urban Paved Sites; Woody Species.
\end{abstract}

Traditionally, a limited number of species and genera dominate the tree stock in city streets and other urban paved sites (in the following simply referred to as urban paved sites). Urban paved sites are defined here as sites where the surface is sealed with hard materials such as concrete, asphalt, paving slabs, or other substances. Recent surveys in European and North American cities show that a few species/genera continue to dominate in these habitats (Pauleit et al. 2002; Raupp et al. 2006; Bühler et al. 2007). Over recent decades, a growing proportion of these commonly used species have shown increasing difficulties in coping with the conditions at urban paved sites. Overall, trees in these environments tend to be greatly exposed to heat, low air humidity, periods of critical water stress, high lime content and high soil $\mathrm{pH}$, limited soil volume, pollutants and de-icing salts (Pauleit 2003; Sieghardt et al. 2005). These negative conditions, combined with the challenges of climate change and the threat of diseases and pest infestations (e.g., Sun 1992; Tello et al. 2005; Raupp et al. 2006), have led to considerable and persistent argumentation for the use of a more varied range of trees, including species selected for stress tolerance, at urban paved sites (Richards 1983; Duhme and Pauleit 2000; Pauleit 2003).

A number of selection programs with the focus on trees for urban sites are underway in different countries (Sæbø et al. 2005). However, the majority of these are concentrating on the genetic aspect of species in current use, with the aim of selecting suitable varieties and genotypes (Santamour 1990; Miller and Miller 1991; Saeb $\varnothing$ et al. 2005). In the case of northern Europe, the majority of species used in cities originate from the native dendroflora, representing cool and moist site conditions. Therefore, limitations in terms of drought and pest tolerance continue to constitute the main problems, despite efforts to select suitable genotypes of existing tree species ( $\mathrm{Sæb} \emptyset$ et al. 2005). To succeed in these selection programs, new tree species must be identified and tested (Duhme and Pauleit 2000).

From the perspective of northern parts of central Europe and adjoining milder parts of northern Europe (in the following abbreviated to the CNE-region), it is unlikely that the species-poor native dendroflora can contribute a large range of tree species with extended tolerance of the environmental stresses characterizing paved sites within urban areas of the region (Duhme and Pauleit 2000). However, other regions with a comparable climate but with a rich dendroflora may have the potential to contribute new tree species and genera well adapted to the growing conditions in urban paved sites in the CNEregion (Takhtajan 1986; Breckle 2002; Roloff et al. 2009).

Water stress is argued to be the main constraint for tree growth and health in the urban environment (e.g., Whitlow and Bassuk 1987; Craul 1999). Research on the drought tolerance of trees has classically focused on physiological reactions in the water balance/water use in terms of transpiration rates, sap flow measurements, and the hydraulic architecture of the tree (e.g., Kozlowski et al. 1991; Sperry et al. 1998; Breda et al. 2006; David et al. 2007; West et al. 2007) These investigations give valuable information at the tree level but are limited in their practical everyday use for urban tree planners and arborists (Roloff et al. 2009). Dendroecological studies, such as that presented in this paper, contribute ecological knowledge that can help evaluate the reaction and tolerance of different trees species to different stressors, and can be a first step in the selection process for 'new' tree species for urban paved sites (Roloff et al. 2009).

In natural habitats, trees have been stress-tested and selected over evolutionary periods of time. Some species have 
developed an extensive plasticity and tolerance of a range of environmental conditions, while others have specialized in certain habitat types (Rabinowitz 1981; Gurevitch et al. 2002). For instance, steep south-facing mountain slopes with thin soil layers represent a distinct habitat type where the environmental parameters that define the particular habitat and separate it from other habitats have shaped the evolution of plants. Such environmental parameters also screen out many potential colonizing species not suited to the particular habitat. Investigating the ecological background and performance of species growing in habitats where they experience drought during the growing season and winter temperatures similar to the CNE-region could be a great help in the identification of trees for future selection for use at urban sites (Flint 1985; Ware 1994; Ducatillion and Dubois 1997; Sæbø et al. 2005; Roloff et al. 2009).

Extensive fieldwork was carried out in the Qinling Mountain range, China, in 2008, to obtain an overview of the species composition, structure, and dynamics of forest systems at altitudes where the climate is similar to that of the inner city across the CNE-region. The study specifically focused on:

* Identification of habitats in the Qinling Mountains where tree species are exposed to seasonally dry and harsh conditions.

* Characterization of the performance of the tree species in these habitats.

* Presentation and discussion of promising tree species for further research and testing regarding use in urban paved sites in northern Europe.

The study forms part of a four-year research program initiated by the Swedish University of Agricultural Sciences to examine selection of site-adapted species for urban paved sites in the CNE-region. Other case study areas are located in northeast Romania and the Caucasus (Georgia). The underlying hypothesis in this selection program is that 'new' tree species for urban use can be identified through studies of natural habitats where trees are exposed to stresses similar to those in the urban paved environment.

\section{MATERIALS AND METHODS}

\section{Case Study Area}

China is considered the most species-rich region in the world (Körner and Spehn 2002; Tang et al. 2006). The Qinling Mountain range in the central, temperate part of the country forms a botanic border between the southern and northern regions of China, and consequently hosts a species-rich flora (Ying and Boufford 1998). Shaanxi province, where the Qinling Mountains are situated, is reported to have 1224 indigenous woody species (Kang pers. comm. 2009), compared with only 166 in the Scandinavian countries (Mossberg and Stenberg 2003). The relatively northern location of the mountain range combined with its high altitudes means that plants are exposed to cold winters and warm summer months with periods of intense drought (Takhtajan 1986; Breckle 2002), conditions comparable to the climate in ur- ban paved sites of the CNE-region. This is especially the case in the many steep, south-facing rocky and craggy slopes.

\section{Site Description}

The field work was carried out within three different areas in the north of the Qinling Mountain range - Taibai Forest Reserve $\left(34^{\circ} 05^{\prime} 10^{\prime \prime} \mathrm{N}, 107^{\circ} 44^{\prime} 46^{\prime \prime} \mathrm{E}\right)$, the Red Valley

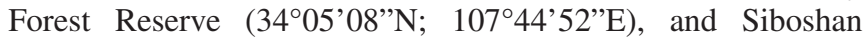

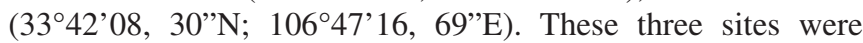
compared against two different site situations (urban paved and urban park) in the inner city environment of Copenhagen (Denmark), which was used as an example to illustrate growth conditions in a large city of the northern CNE-region.

Urban paved sites in Copenhagen currently have a mean annual temperature of $8^{\circ} \mathrm{C}-12^{\circ} \mathrm{C}$ when the urban heat island effect is included $\left(+1^{\circ} \mathrm{C}-3^{\circ} \mathrm{C}\right)$ (DMI 2009; U.S. EPA 2009) and mean annual precipitation of $525 \mathrm{~mm}$ (DMI 2009).

Based on climate data for the Qinling Mountains (Liu and Zhang 2003; Tang and Fang 2006), the altitude zone 1000-1500 $\mathrm{m}$ above sea level (asl.) was identified as the area where mean annual temperature and precipitation matched the climate of urban paved sites in the CNE-region. Mean annual temperature in the area is $9^{\circ} \mathrm{C}-12^{\circ} \mathrm{C}$, mean annual precipitation is $830 \mathrm{~mm}$ and $50 \%$ of the precipitation occurs predominantly during May-July, mainly as heavy rainstorms (Liu and Zhang 2003; Tang and Fang 2006). Botanical experts from the Northwest Agriculture and Forestry University in Yangling assisted in the initial work in order to obtain an overall understanding of the local site conditions. Here, species composition, structure, and dynamics are strongly governed by both altitudinal gradients and cardinal directions.

\section{Woodland Systems Between 1000 and 1500 m asl.}

The forest system between 1000 and $1500 \mathrm{~m}$ asl. comprises deciduous broadleaved oak forest (Liu and Zhang 2003). Quercus aliena var. acuteserrata is the main canopy species throughout the zone. In the lower part of the zone $(<1200 \mathrm{~m}$ asl.), Quercus aliena var. acuteserrata co-dominates with Quercus variabilis, while in higher parts it co-dominates with Quercus wutaishanica. These oak species are particularly dominant on slopes, regardless of direction, whereas the moist river valleys are characterised by mixed broadleaved forests with a large number of other canopy species.

From the steep, south-facing slopes down to the moist and more shaded river valleys, there is a gradual change in the species composition and density of the vegetation. Figure 1 illustrates this change in species composition and density of the vegetation from steep south-facing slopes down to moist and more shaded river valleys. Quercus aliena var. acuteserrata dominates in the canopy layer throughout the slope. Closer to the slope bottom, a dense canopy layer consisting of numerous co-existing broadleaved tree species occurs, in this case Quercus aliena var. acuteserrata co-dominating with the moisture-demanding Toxicodendron veniciflua. In the understory layer, a distinct change occurs in the species composition and density of the vegetation down the slope. The upper part the understory layer is sparse and consists of small trees of Acer davidii and Kalopanax 
pictis. In the lower part, the density gradually increases, with more moisture-demanding tree species such as Cornus kousa var. chinensis and Tilia spp. closer to the slope bottom. The upper part of the diagram is where plot 9 is located. Moreover, in the valleys, tall herbaceous species and a great diversity of shrubs create a dense cover on the forest floor. Larger shrubs and understory trees support an abundance of climbers, some of which even reach into the dense canopy layer created by a large number of co-existing broadleaved tree species (Table 1).

Compared with the river valleys, the forest system on northfacing slopes has less vigorous field layers, while shrubs and climbers are more scattered. However, the understory vegetation is still well developed and contains numerous species, as illustrated in Figure 2. Oak species dominate the canopy, with Quercus aliena var. acuteserrata as the main species independent of slope direction (Table 1). The difference in species composition and vegetation structures between south- and north-facing slopes is striking. South-facing slopes have irregular field layers and both the shrub and understory layers are sparse and mainly consist of younger individuals of the canopy species, together with Cotinus coggygria. In the lower parts of the zone $(<1200$ $\mathrm{m}$ asl.), the semi-evergreen Quercus baronii is a common species in the understory and canopy layer on south slopes, where it can apparently dominate locally (Table 1 ). On the south slope, which is where plot 1 was located, there are three oak species (Figure 2): Quercus aliena var. acuteserrata and $Q$. wutaishanica in the canopy layer, and $Q$. baronii in the understory layer. The southfacing slopes have much sparser vegetation than the moister north-facing slopes, which have significantly denser vegetation and contain more moisturedependent tree species such as AcergriseumandSorbusalnifolia.

The forest systems on eastand west-facing slopes are a combination of the structures and species composition found on the south- and north-facing slopes.

Among the species observed in these forest sysAnders Busse Nielsen.

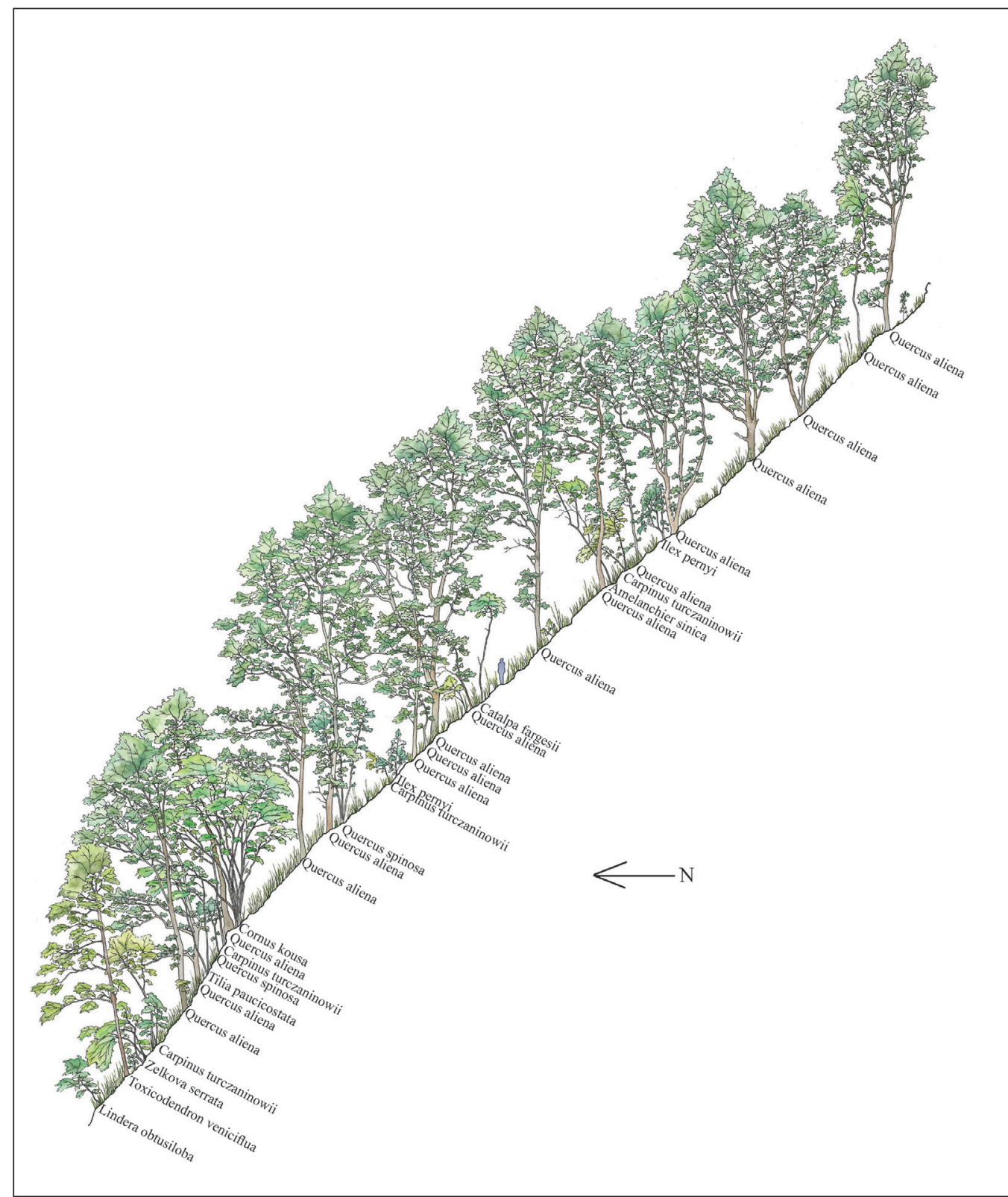

Figure 1. Profile diagram illustrating change in species composition and density of the vegetation from steep south-facing slopes down to moist and more shaded river valleys. Illustration courtesy of tems, only a limited number occur continuously throughout the zone studied here (1000-1500 m asl.) (Table 1). This is partly because they have their main distribution in lower or higher terrain, and partly because some species are rare across the entire mountain range. Examples of species with their main distribution in higher terrain are Ilex pernyi, $\mathrm{Ka}$ lopanax pictus, Pinus armandii, Quercus spinosa, and Tilia paucicostata, while Cercis chinensis and Quercus variabilis have their main distribution in lower terrain. Crataegus pinnatifida and Zelkova serrata are examples of rare species, and only a few individuals are present throughout the mountain range, regardless of slope aspect or site condition. 


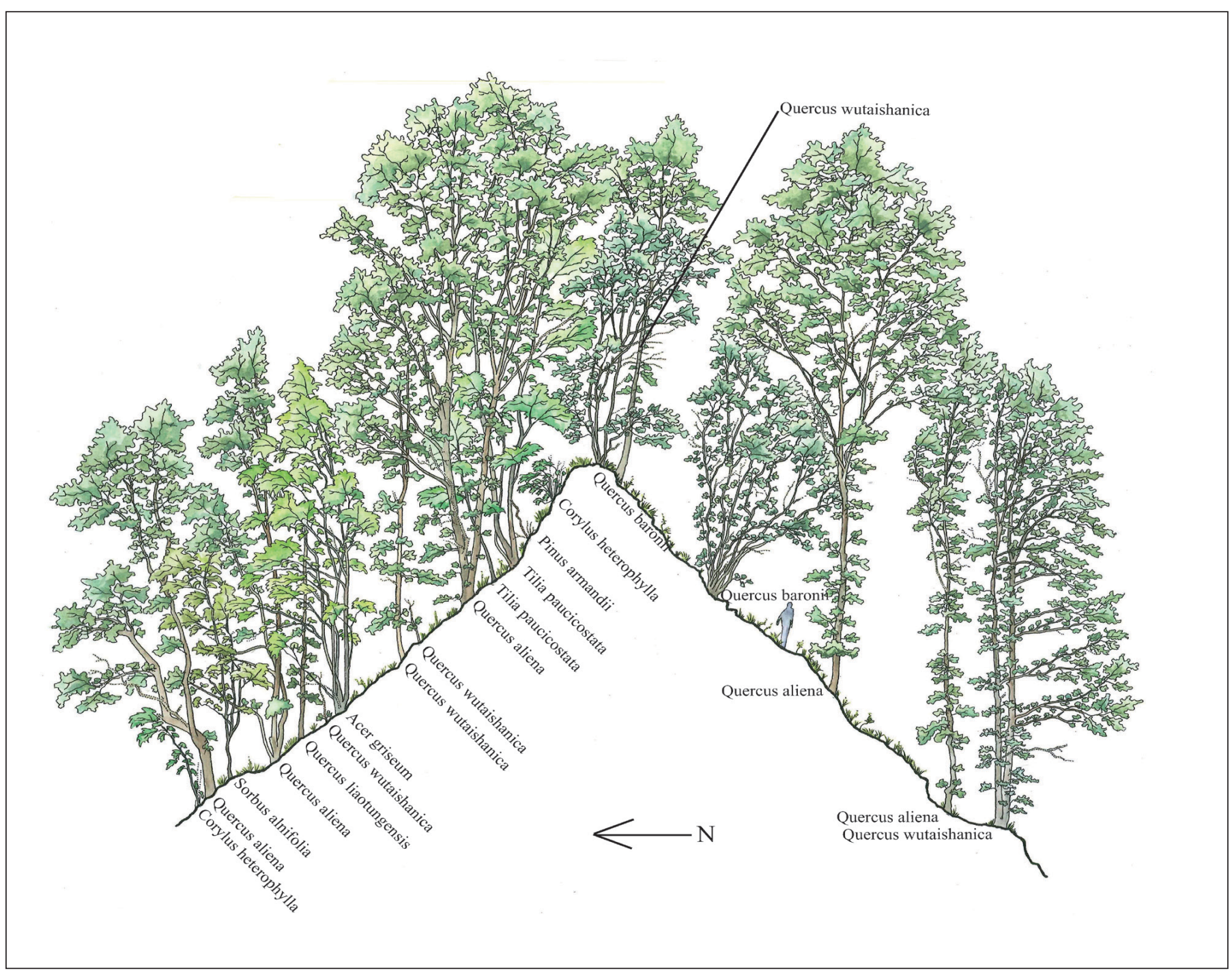

Figure 2. Profile diagram illustration changes in species composition and vegetation structure between south- and north-facing slopes. Illustration courtesy of Anders Busse Nielsen.

\section{Location of Plots}

The field work was conducted during March-October 2008 with the assistance of botanical experts from the Northwest Agriculture and Forestry University, Yangling. Special attention was paid to identifying the exact location of steep, southfacing slopes with shallow soils and rock outcrops, so that the range of tree species capable of growing in these locations could be identified. Subsequently, 20 study plots were strategically placed on recognized south-facing slopes where the presence of a mature tree population on exceedingly rocky and/or steep gradients was the main criterion. Homogeneous site conditions with the greatest range of species determined the exact location and size of each plot. Plot size was $10 \mathrm{~m}$ $\times 10 \mathrm{~m}$ or $30 \mathrm{~m} \times 30 \mathrm{~m}$, and plots were located between 1150 and $1590 \mathrm{~m}$ asl. (Table 2). Since local site conditions differ greatly within small distances throughout the mountain area, only one plot could be bigger than $10 \mathrm{~m} \times 10 \mathrm{~m}$. Plots below $1150 \mathrm{~m}$ asl. were not selected for the survey due to human impacts on vegetation and species composition.

\section{Measurement of Plot Data}

For each plot: slope aspect and steepness were measured and degree of rock outcrop and cover of the herbaceous field layer were estimated. Assessment of the exposure of bedrock was based on FAO (2006). The field layer cover was estimated at intervals of $10 \%$.

For comparisons between the natural habitats and urban paved conditions in the CNE-region, soil texture, humus content, and $\mathrm{pH}$ value were examined in detail. Soil samples were collected at three different depths $(0-20,20-30,30-50 \mathrm{~cm})$ from 10 pits randomly distributed in each plot (Klute 1986; FAO 2006). The samples taken from each depth were mixed before analysis (FAO 2006). Soil texture was analyzed using the soil grain analysis method (Ehrlich and Weinberg 1970), organic matter content using the $\mathrm{K}_{2} \mathrm{Cr}_{2} \mathrm{O}_{4}$ method (Sims and Haby 1971), and pH using the potentiometric determination method (soil/water $=1: 2.5)($ Tan 2005).

All trees were measured for diameter at breast height (DBH), total height and age in order to determine growth and development. To establish age, all trees were subjected to drilling for growth 
Table 1. Tree species distributed to their main habitat in the altitude band 1000-1500 $\mathrm{m}$ asl. and their position in the woodland structure - canopy (c) and understory (u) species. Capital letters indicate their main position in the structure.

\begin{tabular}{|c|c|c|c|}
\hline Species & River valleys & North-facing slopes & South-facing slopes \\
\hline Acer davidii & $\mathrm{U}$ & - & - \\
\hline Acer grosseri & $\mathrm{U}$ & - & - \\
\hline Acer mono & $\mathrm{u} / \mathrm{c}$ & - & - \\
\hline Acer griseum & - & $\mathrm{u} / \mathrm{c}$ & - \\
\hline Acer henryii & $\mathrm{u} / \mathrm{c}$ & $\mathrm{u} / \mathrm{c}$ & - \\
\hline Aesculus chinensis & $\mathrm{c}$ & - & - \\
\hline Ailanthis altissima & - & - & $\mathrm{u} / \mathrm{c}$ \\
\hline Amelanchier sinica & - & $\mathrm{u} / \mathrm{c}$ & - \\
\hline Carpinus cordata & $\mathrm{u} / \mathrm{c}$ & - & - \\
\hline Carpinus turczaninowii & - & $\mathrm{u} / \mathrm{c}$ & $\mathrm{u} / \mathrm{c}$ \\
\hline Celtis bungeana & - & - & $\mathrm{u} / \mathrm{c}$ \\
\hline Cercidiphyllum japonica & $\mathrm{u} / \mathrm{c}$ & - & - \\
\hline Cercis chinensis & - & - & $\mathrm{c}$ \\
\hline Cladastris sinensis & $\mathrm{u} / \mathrm{c}$ & $\mathrm{u} / \mathrm{c}$ & - \\
\hline Cornus controversa & $\mathrm{u} / \mathrm{c}$ & - & - \\
\hline Cornus kousa var. chinensis & $\mathrm{u}$ & $\mathrm{u}$ & - \\
\hline Cornus macrophylla var. macrophylla & $\mathrm{u} / \mathrm{c}$ & - & - \\
\hline Crataegus pinnatifida & $\mathrm{u}$ & $\mathrm{u}$ & $\mathrm{u}$ \\
\hline Corylys chinensis & $\mathrm{u} / \mathrm{c}$ & - & - \\
\hline Dipteronia sinensis & $\mathrm{u} / \mathrm{c}$ & - & - \\
\hline Euodia daniellii & $\mathrm{u} / \mathrm{c}$ & $\mathrm{u} / \mathrm{c}$ & - \\
\hline Euptelia pleiosperma & $\mathrm{u}$ & - & - \\
\hline Fraxinus chinensis & - & $\mathrm{u} / \mathrm{c}$ & $\mathrm{u} / \mathrm{c}$ \\
\hline Fraxinus mandchurica & $\mathrm{u} / \mathrm{c}$ & - & - \\
\hline Hovenia dulcis & $\mathrm{u} / \mathrm{c}$ & - & - \\
\hline Juglans cathayensis & $\mathrm{u} / \mathrm{c}$ & - & - \\
\hline Ilex perney & - & $\mathrm{u}$ & $\mathrm{u}$ \\
\hline Kalopanax pictus & - & $\mathrm{u} / \mathrm{c}$ & $\mathrm{u}$ \\
\hline Koelreuteria paniculata & - & - & $\mathrm{u} / \mathrm{c}$ \\
\hline Lindera obtusiloba & $\mathrm{U}$ & $\mathrm{U}$ & - \\
\hline Magnolia sprengeri & $\mathrm{u} / \mathrm{c}$ & $\mathrm{u} / \mathrm{c}$ & - \\
\hline Morus mongolica & - & - & $\mathrm{u} / \mathrm{c}$ \\
\hline Ostrya japonica & - & - & $\mathrm{u} / \mathrm{c}$ \\
\hline Pinus armandii & - & $\mathrm{U}$ & $\mathrm{U}$ \\
\hline Populus purdomii & $\mathrm{C}$ & - & - \\
\hline Pterocarya insignis & $\mathrm{u} / \mathrm{c}$ & - & - \\
\hline Quercus aliena var. acuteserrata & $\mathrm{u} / \mathrm{c}$ & $\mathrm{u} / \mathrm{c}$ & $\mathrm{U} / \mathrm{C}$ \\
\hline Quercus baronii & - & - & $\mathrm{U} / \mathrm{C}$ \\
\hline Quercus wutaishanica & $\mathrm{u} / \mathrm{c}$ & $\mathrm{u} / \mathrm{c}$ & $\mathrm{C}$ \\
\hline Quercus spinosa & - & - & $\mathrm{u}$ \\
\hline Quercus variabilis & - & - & $\mathrm{u}$ \\
\hline Rhus potaninii & $\mathrm{u} / \mathrm{c}$ & $\mathrm{u} / \mathrm{c}$ & $\mathrm{u}$ \\
\hline Salix sp. & $\mathrm{C}$ & - & - \\
\hline Sorbus alnifolia & $\mathrm{u} / \mathrm{c}$ & $\mathrm{u}$ & - \\
\hline Sorbus folgneri & - & $\mathrm{u} / \mathrm{c}$ & $\mathrm{u} / \mathrm{c}$ \\
\hline Staphylea holocarpa & $\mathrm{u}$ & $\mathrm{u}$ & - \\
\hline Syringa pekinenis & - & - & $\mathrm{u} / \mathrm{c}$ \\
\hline Tilia paucicostata & - & $\mathrm{u}$ & $\mathrm{u}$ \\
\hline Tilia $\mathrm{sp}$ & $\mathrm{u} / \mathrm{c}$ & $\mathrm{u} / \mathrm{c}$ & - \\
\hline Toxicodendron veniciflua & $\mathrm{u} / \mathrm{c}$ & $\mathrm{u} / \mathrm{c}$ & - \\
\hline Ulmus glausescens & - & - & $\mathrm{U} / \mathrm{C}$ \\
\hline Ulmus pumila & - & - & $\mathrm{u} / \mathrm{c}$ \\
\hline Zelkova serrata & $\mathrm{u} / \mathrm{c}$ & $\mathrm{u} / \mathrm{c}$ & $\mathrm{c}$ \\
\hline
\end{tabular}

ring counts as close to the ground as possible (Grissino-Mayer 2003). Tree positions were surveyed to distinguish canopy from understory and tree growth habit was recorded as single-stemmed or multi-stemmed (Table 3). In addition, profile diagrams were drawn for three study plots and the surroundings in order to demonstrate vegetation structures with species composition and positions. Two such diagrams are presented in Figure 1 and Figure 2.

\section{Calculation of Potential Water Stress}

The potential water stress in the study plots was calculated and compared with data for the inner city environment of Copenha- gen (Figure 3). For calculation of potential evapotranspiration, the regression by Thornthwaite (1948) was used, with monthly potential evapotranspiration based on values of temperature, number of sunshine hours per day, and cloudiness. Sunshine hours per day were estimated on a monthly basis by combining information about day length (Meeus 1991) and days with rainfall as an indicator of cloudiness (Liu and Zhang 2003). Cloudiness was taken as $10 \%$ of the total day length except in the rainiest months (May, June, and July), when it was taken as $50 \%$ (Liu and Zhang 2003). Since data on water runoff were not available for the study plots, data for an area with similar topography and vegetation characteristics in the region of Yang- 
ping were used, with $62 \%$ water runoff (Lin et al. 2007). Mean annual precipitation in Yangping exceeds that in Qinling by 215 $\mathrm{mm}$, but the runoff data were considered suitable as the distribution and intensity of rain were closely correlated in both areas.

Estimates of water runoff data for park environments and urban paved areas of Copenhagen were based on P90 (2004), including $10 \%$ runoff from park environments and an expected $70 \%$ water runoff from paved areas.

\section{RESULTS}

\section{Study Plots: Soil and Surface Conditions}

In all plots except three (plots 3, 5, and 11), soil depth was at least $50 \mathrm{~cm}$, indicating that tree roots can penetrate into deeper soil (Table 2). However, shallow bedrock and rock outcrops partly limited the soil depth in the majority of the plots (Table 2). The soil texture was similar for all plots, with high to very high levels of silt (mean 53\%) and low contents of clay (mean 2.3\%) (Table 2). The organic matter content was also low across the plots (mean $36.3 \mathrm{~g} / \mathrm{kg}$ ) (Table 2).

\section{Study Plots: Cumulative Water Net and Surface Runoff}

With regard to the present situation in Copenhagen, the negative water status for urban paved areas gradually increases from April onwards, while there is an increase in surface runoff in the autumn and winter. Park environments in Copenhagen experience partial water stress from June, with a less dramatic trend throughout the season (Figure 3). Under current conditions on steep south-facing slopes in the Qinling Mountains at 1000-1500 m asl., the plots experienced partial water stress in April and June, and more severe water stress in July and the remainder of the growing season (Figure 3). Hence, there is a clear discrepancy between the water stress status in Qinling and that in paved sites of Copenhagen today. This is mainly due to the higher precipitation rate in Qinling, as the area receives an additional $287 \mathrm{~mm}$ rain in the summer season (May-September) compared with Copenhagen. However, temperatures during the corresponding period are $4.7^{\circ} \mathrm{C}$ higher at the study site in China, which leads to much more efficient evapotranspiration compared with Copenhagen.

\section{Study Plots Species Composition and Performance}

A total 306 trees divided between 25 species representing 21 genera were found in the study plots (Table 3 ). Combining the plot data with general observations on species occurrence across the woodland systems revealed that a large proportion of the 25 species mainly or exclusively grow on steep, south-facing slopes, while other species occur both on south-facing slopes and in valleys and slopes with different orientations (Table 1).

Acer davidii, Kalopanax pictus, Pinus armandii, Quercus spinosa, Rhus potaninii, and Tilia paucicostata were present in great numbers in river valleys and north-facing slopes, where they develop into large canopy trees (Table 1), while their occurrence on hot and dry south-facing slopes was more scattered. On the latter, their growth is slow and/or underdeveloped, primarily occurring in the understory (Table 3). In contrast, Ailanthus altissima, Carpinus turczaninowii, Celtis bungeana, Cercis chinensis, Fraxinus chinensis, Koelreuteria paniculata, Morus mongolica, Ostrya japonica, Quercus aliena var. acuteserrata, $Q$. baronii, $Q$. wutaishanica, Sorbus folgneri, Syringa pekinensis, Ulmus glausescens, and Ulmus pumila were mainly found on steeper parts of south-facing slopes, where they develop into tall, old trees (Table 1; Table 3).

Based on the numbers of individual trees, age and growth (height and DBH) (Table 3), it is possible to divide the 25 tree species into two groups. Group 1 includes the species which have their main presence in river valleys or on north-facing slopes, whereas on steep south-facing slopes they are small and/or slow-growing individuals. Group 2 includes species which develop into tall, old trees on steep south-facing slopes at altitudes between 1000 and $1500 \mathrm{~m}$ asl. The exceptions to this grouping

Table 2. Compilation of plot data. Rock outcrops in the plots were classified as $\mathrm{N}$ (None $0 \%$ ), V (Very Few $0 \%-2 \%$ ), $\mathrm{F}$ (Few $2 \%-5 \%$ ), C (Common 5\%-15\%), M (Many $15 \%-40 \%$ ), A (Abundant $40 \%-80 \%$ ), or D (Dominant $>80 \%$ ).

\begin{tabular}{|c|c|c|c|c|c|c|c|c|c|c|c|}
\hline $\begin{array}{l}\text { Plot } \\
\text { no. }\end{array}$ & $\begin{array}{l}\text { Altitude } \\
\text { (m asl.) }\end{array}$ & $\begin{array}{l}\text { Slope } \\
\text { aspect }\end{array}$ & $\begin{array}{l}\text { Slope } \\
\text { steepness } \\
\text { (degree) }\end{array}$ & $\begin{array}{l}\text { No. soil samples } \\
(30-50 \mathrm{~cm})\end{array}$ & $\mathrm{pH}$ & $\begin{array}{l}\text { Rock } \\
\text { outcrops }\end{array}$ & $\begin{array}{l}\text { Field layer } \\
\text { cover }(\%)\end{array}$ & $\begin{array}{l}\text { Plot size } \\
(\mathrm{m})\end{array}$ & $\begin{array}{l}\text { Organic } \\
\text { matter } \\
(\mathrm{g} / \mathrm{kg})\end{array}$ & $\begin{array}{l}\text { Clay } \\
\text { content } \\
(\%)\end{array}$ & $\begin{array}{l}\text { Silt } \\
\text { content } \\
(\%)\end{array}$ \\
\hline 1 & 1490 & South & 64 & 7 & 6.7 & $\mathrm{~F}$ & 20 & $10 \times 10$ & 17.4 & 3.0 & 63.0 \\
\hline 3 & 1160 & Southwest & 53 & $0(\max 25 \mathrm{~cm})$ & 6.5 & $\mathrm{C}$ & 20 & $10 \times 10$ & 65.6 & 2.2 & 56.8 \\
\hline 4 & 1190 & South/Southwest & 50 & 9 & 6.6 & $\mathrm{~F}$ & 30 & $10 \times 10$ & 29.3 & 2.7 & 56.7 \\
\hline 5 & 1220 & South/Southeast & 51 & $0(\max 25 \mathrm{~cm})$ & 6.0 & A & 30 & $10 \times 10$ & 89.6 & 2.2 & 47.0 \\
\hline 6 & 1400 & Southwest & 43 & 10 & 6.4 & $\mathrm{~F}$ & 10 & $10 \times 10$ & 18.8 & 2.0 & 48.2 \\
\hline 8 & 1350 & Southwest & 43 & 5 & 6.0 & $\mathrm{C}$ & 50 & $10 \times 10$ & 21.8 & 3.0 & 61.9 \\
\hline 9 & 1590 & South & 40 & 10 & 7.2 & V & 20 & $10 \times 10$ & 41.3 & 2.7 & 59.4 \\
\hline 10 & 1560 & South/Southeast & 43 & 10 & 7.6 & $\mathrm{~N}$ & 20 & $10 \times 10$ & 23.0 & 2.5 & 52.7 \\
\hline 11 & 1280 & South & 20 & $0(\max 20 \mathrm{~cm})$ & 7.3 & A & 20 & $10 \times 10$ & 59.4 & 1.3 & 33.6 \\
\hline 12 & 1290 & South & 44 & 6 & 6.8 & M & 30 & $30 \times 30$ & 39.3 & 2.6 & 54.5 \\
\hline 13 & 1280 & South/Southwest & 35 & 6 & 6.9 & M & 40 & $10 \times 10$ & 48.0 & 1.4 & 41.7 \\
\hline 14 & 1260 & South & 45 & 2 & 6.4 & $\mathrm{C}$ & 30 & $10 \times 10$ & 51.1 & 1.6 & 45.7 \\
\hline 15 & 1370 & South & 44 & 6 & 6.9 & $\mathrm{~V}$ & 40 & $10 \times 10$ & 31.0 & 2.5 & 53.8 \\
\hline 17 & 1410 & South/Southwest & 49 & 2 & 6.8 & A & 10 & $10 \times 10$ & 54.8 & 1.6 & 44.0 \\
\hline 18 & 1350 & South/Southwest & 44 & 6 & 6.5 & $\mathrm{C}$ & 40 & $10 \times 10$ & 22.6 & 3.0 & 60.2 \\
\hline 19 & 1390 & Southeast & 43 & 7 & 5.8 & $\mathrm{~F}$ & 30 & $10 \times 10$ & 16.8 & 3.0 & 58.6 \\
\hline 20 & 1360 & South & 45 & 5 & 6.5 & A & 10 & $10 \times 10$ & 44.8 & 1.9 & 47.5 \\
\hline Mear & & & & & 6.7 & & 27 & & 36.3 & 2.3 & 53.0 \\
\hline
\end{tabular}


system are Crataegus pinnatifida, Ilex pernyi, and Zelkova serrata, which are present in small numbers throughout the mountain range, regardless of slope aspect and site condition and need further investigation in order to determine their appropriate grouping. Cercis chinensis and Quercus variabilis both belong to woodland types at lower altitudes and they occur only infrequently in the 1000-1500 m asl. altitude zone, which makes it difficult to draw any conclusions (Table 3).

The most common tree species on steeper parts of south-facing slopes, Quercus baronii and Ulmus glausescens, were present in the canopy as well as in the understory. They represented $42 \%$ of all trees in the study plots, with 96 and 34 trees, respectively (Table 3). Among the other tree species that had developed into tall, old trees (Group

2 ), the majority occurred in rather small numbers and were found as scattered individuals or in small groups throughout the vegetation systems, although mainly on steep south-facing slopes. Furthermore, all the trees belonging to Group 2 occurred in the understory layer as well as in the canopy layer (Table 3), indicating tolerance to the warmer and drier conditions prevailing in the canopy layer compared with that underneath the tree crowns.

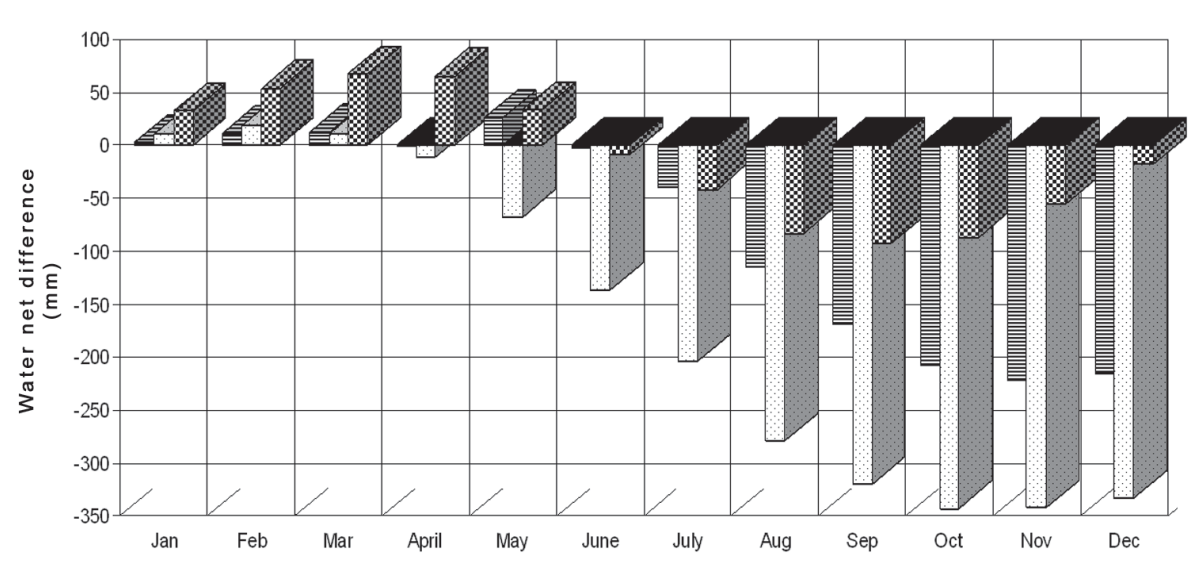

目 Qinling Mountain 1000-1500m asl 미 Copenhagen (Paved environment) : Copenhagen (Park environment)

Figure 3. Calculated potential evapotranspiration $(\mathrm{mm})$ in the study plots on steep south-facing slopes at 1000-1500 m asl. in the Qinling Mountains and in urban paved environments and park environments of Copenhagen today.

When the performance (height and DBH versus age) of trees from the 14 species belonging to Group 2 was examined, a common pattern emerged. There was a lack of young individuals among many of the species except for Carpinus turczaninowii, Fraxinus chinesnis, Quercus baronii, Sorbus folgneri, and Ulmus glausescens, for which there was an even age span (Table 3). Many of the tree species found in the study plots developed into smaller trees compared with known specimens of the same

Table 3. Compilation of the tree species and the number of individuals found in the study plots. The age of the species is presented as youngest and oldest individual. The performance of the trees differed between single-stemmed trees and multi-stemmed trees. Vertical distribution of trees divided into upper tree layer and lower tree layer. Height $(\mathrm{m})$ and trunk diameter growth (DBH) $(\mathrm{cm})$ are presented for the smallest and largest individuals within the species. The species are divided into two groups based on age and growth (height and DBH), where Group 1 includes the species with their main presence in river valleys or on northfacing slopes, whereas on steep south-facing slopes they are small and/or slow-growing individuals. Group 2 includes species which develop into tall, old trees on steep south-facing slopes at altitudes between 1000 and $1500 \mathrm{~m}$ asl.

\begin{tabular}{|c|c|c|c|c|c|c|c|}
\hline Species & $\begin{array}{l}\text { No. of } \\
\text { trees }\end{array}$ & $\begin{array}{l}\text { Single stemmed } \\
\text { /multi-stemmed }\end{array}$ & $\begin{array}{l}\text { Upper/lower } \\
\text { tree layer }\end{array}$ & $\begin{array}{l}\text { Age } \\
\text { min./max. }\end{array}$ & $\begin{array}{l}\text { Height }(\mathrm{m}) \\
\text { min./max. }\end{array}$ & $\begin{array}{l}\mathrm{DBH}(\mathrm{cm}) \\
\min . / \max .\end{array}$ & Group \\
\hline Acer davidii & 2 & $2 / 0$ & $0 / 2$ & $8 / 33$ & $2 / 4$ & $1 / 4.5$ & 1 \\
\hline Ailanthus altissima & 14 & $14 / 0$ & $10 / 4$ & $32 / 84$ & $8 / 21$ & $8.6 / 43$ & 2 \\
\hline Carpinus turczaninowii & 15 & $9 / 4$ & $6 / 9$ & $13 / 96$ & $2 / 13$ & $1.6 / 28.3$ & 2 \\
\hline Celtis bungeana & 12 & $12 / 0$ & $10 / 2$ & $26 / 84$ & $4.5 / 19.5$ & $3.2 / 24.2$ & 2 \\
\hline Cercis chinensis & 1 & $1 / 0$ & $1 / 0$ & 118 & 24 & 34.4 & - \\
\hline Crataegus pinnatifida & 2 & $2 / 0$ & $0 / 2$ & $-/ 51$ & $4.5 / 11$ & $5.1 / 16.6$ & - \\
\hline Fraxinus chinensis & 8 & $7 / 1$ & $4 / 4$ & $14 / 67$ & $1.5 / 9$ & $1.6 / 67$ & 2 \\
\hline Ilex pernyi & 1 & $0 / 1$ & $0 / 1$ & 53 & 8 & 14.3 & - \\
\hline Kalopanax pictus & 4 & $4 / 0$ & $0 / 4$ & $5 / 10$ & $1 / 2$ & $1 / 1.9$ & 1 \\
\hline Koelreuteria paniculata & 13 & $8 / 5$ & $12 / 1$ & $47 / 76$ & $9 / 20$ & $9.9 / 31.5$ & 2 \\
\hline Morus mongolica & 6 & $5 / 1$ & $5 / 1$ & $44 / 74$ & $5 / 11$ & $6.7 / 24.8$ & 2 \\
\hline Ostrya japonica & 5 & $2 / 3$ & $4 / 1$ & $25 / 69$ & $4.5 / 12$ & $6.4 / 22.3$ & 2 \\
\hline Pinus armandii & 1 & $1 / 0$ & $0 / 1$ & 19 & 4 & 3.8 & 1 \\
\hline Quercus aliena & 23 & $18 / 5$ & $15 / 9$ & $19 / 82$ & $1.5 / 23.5$ & $2.5 / 31.2$ & 2 \\
\hline Quercus baronii & 96 & $46 / 50$ & $44 / 52$ & $7 / 139$ & $0.5 / 16$ & $1 / 32.2$ & 2 \\
\hline Quercus wutaishanica & 14 & $9 / 5$ & $14 / 0$ & $39 / 101$ & $10 / 22$ & $16.6 / 43.3$ & 2 \\
\hline Quercus spinosa & 1 & $1 / 0$ & $0 / 1$ & 32 & 4 & 6.7 & 1 \\
\hline Quercus variabilis & 1 & $1 / 0$ & $0 / 1$ & 42 & 7 & 8.9 & - \\
\hline Rhus potaninii & 1 & $1 / 0$ & $0 / 1$ & 35 & 6.5 & 11.5 & 1 \\
\hline Sorbus folgneri & 17 & $17 / 0$ & $5 / 12$ & $9 / 67$ & $1.5 / 11.5$ & $1.6 / 14.6$ & 2 \\
\hline Syringa pekinensis & 6 & $5 / 2$ & $2 / 4$ & $11 / 64$ & $3.5 / 11.5$ & $4.1 / 19.7$ & 2 \\
\hline Tilia paucicostata & 1 & $1 / 0$ & $0 / 1$ & 36 & 7.5 & 10.2 & 1 \\
\hline Ulmus glaucescens & 34 & $26 / 8$ & $23 / 11$ & $12 / 82$ & $2 / 20$ & $2.2 / 28$ & 2 \\
\hline Ulmus pumila & 25 & $18 / 7$ & $8 / 17$ & $28 / 76$ & $3 / 9.5$ & $5.1 / 15$ & 2 \\
\hline Zelkova serrata & 2 & $2 / 0$ & $2 / 0$ & $53 / 63$ & $10.5 / 13.5$ & $13.7 / 24.8$ & - \\
\hline
\end{tabular}


Table 4. Mean value for yearly height growth and diameter growth followed by mean tree height and DBH at age 15 and 50 years for tree species belonging to Group 2 .

\begin{tabular}{lllll}
\hline Species & $\begin{array}{l}\text { Yearly height } \\
\text { growth }(\mathrm{m})\end{array}$ & $\begin{array}{l}\text { Yearly diameter } \\
\text { growth }(\mathrm{cm})\end{array}$ & $\begin{array}{l}\text { Size of } \\
\text { 15-year-old tree } \\
\text { height/DBH }\end{array}$ & $\begin{array}{l}\text { Size of } \\
\text { 50-year-old tree } \\
\text { height/DBH }\end{array}$ \\
\hline A. altissima & 0.26 & 0.36 & $3.9 / 5.4$ & $13 / 18$ \\
C. turczaninowii & 0.16 & 0.26 & $2.4 / 3.9$ & $8 / 13$ \\
C. bungeana & 0.16 & 0.21 & $2.4 / 3.2$ & $8 / 10.5$ \\
F. chinensis & 0.16 & 0.23 & $2.4 / 3.5$ & $8 / 11.5$ \\
K. paniculata & 0.25 & 0.40 & $3.9 / 6$ & $12.5 / 20$ \\
M. mongolica & 0.16 & 0.30 & $2.4 / 4.5$ & $8 / 15$ \\
O. japonica & 0.19 & 0.32 & $2.9 / 4.8$ & $9.5 / 16$ \\
$Q$. aliena & 0.24 & 0.36 & $3.6 / 5.4$ & $12 / 18$ \\
$Q$. baronii & 0.14 & 0.23 & $2.1 / 3.5$ & $7 / 11.5$ \\
Q. wutaishanica & 0.25 & 0.35 & $3.8 / 5.3$ & $12.5 / 17.5$ \\
S. folgneri & 0.22 & 0.23 & $3.3 / 3.5$ & $11 / 11.5$ \\
S. pekinensis & 0.21 & 0.30 & $3.2 / 4.5$ & $10.5 / 15$ \\
U. glaucescens & 0.17 & 0.22 & $2.6 / 3.3$ & $8.5 / 11$ \\
U. pumila & 0.12 & 0.20 & $1.8 / 3$ & $6 / 10$ \\
\hline
\end{tabular}

species on wetter sites. However, species such as Ailanthus altissima, Koelreuteria paniculata, Quercus aliena, Q. wutaishanica, Sorbus folgneri, and Syringa pekinenis had a yearly height increment of over $20 \mathrm{~cm}$ in the study plots and develop into $10-13 \mathrm{~m}$ high trees in approximately 50 years, while the other species in this group can develop into almost $10 \mathrm{~m}$ high trees during same period (Table 4). The calculations presented in Table 4 are based on rather few individuals, but can still be used as an indicator of their growth in these climate and site conditions.

\section{DISCUSSION}

\section{Site Conditions}

This study examined forest systems occurring between 1000$1500 \mathrm{~m}$ asl. in the Qinling Mountains, in order to identify tree species growing and developing satisfactorily in natural habitats with similarities to those found in urban paved sites in the CNE-region. The mean annual temperature on south-facing slopes within the altitude band studied is comparable to that in inner city conditions in the CNE-region $\left(8^{\circ} \mathrm{C}-12^{\circ} \mathrm{C}\right)$. The direct exposure to sunlight on the slopes also creates low air humidity and rapid drying of the soil, which is comparable to the situation on many urban paved sites (Sieghardt et al. 2005). In addition, the low organic matter content (mean $36.3 \mathrm{~g} / \mathrm{kg}$ ) and neutral $\mathrm{pH}$ (mean 6.7) of the study plot soils are similar to values reported for urban sites (Craul 1999).

Among the multiple stress factors that characterize urban paved sites, water stress is argued to be the main constraint for tree growth and health (e.g., Whitlow and Bassuk 1987; Craul 1999). The high silt content of the soils in the Qinling Mountains plots means they have good water-holding capacity, but as the surface of bare silty soil dries surface has a tendency to form a hard crust, which can cause extensive water runoff (Brady and Weil 2002). This characteristic is further exaggerated on steep slopes with sparse field layers (mean cover 27\%) and frequent rock outcrops, like the plots studied (Table 2).

In terms of estimated potential water stress, the forest systems on steep south-facing slopes between 1000-1500 m asl. in the Qinling Mountains showed a clear discrepancy with paved sites of Copenhagen today. The net water deficit appeared in the study plots in April but only became severe in July, consider- ably later and less severe than in the present situation in paved sites of Copenhagen (Figure 3). However since Copenhagen has a maritime climate while the study plots are in a continental climate, the match between the Qinling Mountains plots and paved sites of present day Copenhagen is probably closer than illustrated in Figure 3. Moreover, as the water runoff data used in calculating the potential water stress levels were not taken directly from the Qinling Mountains, the estimated water stress levels should be interpreted with caution.

\section{Species Composition and Performance}

The plot data combined with general observations of tree species occurrence across woodland systems in river valleys and slopes with different orientations showed that some of the species present have developed an extensive plasticity and tolerance toward a range of environmental conditions (habitat generalists), while others have specialized in the distinct habitat type on south-facing slopes (habitat specialists).

Based on the observation together with botanical experts from the Northwest Agriculture and Forestry University, Yangling, the habitat generalists occurred on south-facing slopes, but have their main distribution in valleys and on slopes with other aspects (Table 1). When these species grow on steep south-facing slopes they develop slowly and are primarily found in the understory (Table 3), where the shading canopy reduces the temperature and is likely to increase the air humidity. In comparison, the species that have specialized in the distinct habitat on south-facing slopes occur as tall canopy trees as well as younger individuals in the understory (Table 3 ). The capacity to develop into tall, old trees indicates a broad and long-standing adaptation of these species to the harsh conditions characterizing this type of habitat. As suggested by Flint (1985), Ware (1994), and Duhme and Pauleit (2000), this ecological background makes the group of habitat specialists identified interesting for future selection of trees for use in urban paved environments.

Habitat specialists for warm and dry south-facing slopes at $1000-1500 \mathrm{~m}$ asl. in Qinling (Group 2) included Ailanthus altissima, Carpinus turczaninowii, Celtis bungeana, Fraxinus chinensis, Koelreuteria paniculata, Morus mongolica, Ostrya japonica, Quercus aliena var. acuteserrata, $Q$. baronii, $Q$. wutaishanica, Sorbus folgneri, Syringa pekinensis, Ulmus glausescens, and Ulmus pumila. These species have developed different ecological strategies to cope with warm and dry habitats where water stress occurs. Such strategies include development of leaves with a thick cuticle to prevent excessive transpiration, which is the case for Koelreuteria paniculata (Balok and Hilaire 2002). Large and deep-penetrating root systems enabling the plant to find water in lower soil layers is another successful strategy employed by many broadleaved oak species, such as Quercus aliena var. acuteserrata and Q. wutaishanica (Spurr and Barnes 1980; Gale and Grigal 1987; Kozlowski et al. 1991). In addition, wintergreen oak species such as Quercus baronii can photosynthesize during cooler and moister periods of the year, which allows them to reduce activity in periods with severe water stress (Corcuera et al. 2002). In the CNE-region, the first two of these strategies would appear to be effective at urban paved sites but deep rooting would only be possible if they are given a deep planting bed. Furthermore, the frozen ground during winter could cause dehydration problems for evergreen trees at dry urban paved sites. Moreover 
the lack of young trees among the majority of the species indicates the pioneer strategy among these heat- and drought-tolerant tree species, which have high demands for sunlight and therefore difficulties in establishing under tree canopies. This pioneer strategy also explains the age distribution of some of the species. In the case of Ailanthus altissima and Koelreuteria paniculata, for example, the age distribution was more uneven, since their establishment took place during a specific time period (e.g., when a light 'window' opened after a landslide). This can be compared with the more shade-tolerant Carpinus turczaninowii, individuals of which were spread among the age classes (Table 3).

There was great variation between a single-stemmed and multi-stemmed growth habit for approximately $50 \%$ of the 25 tree species observed in the plots (Table 3). This might be attributable to genetic variation within the species, but is also possible that the multi-stemmed growth is a result of previous coppicing. This is much more likely to be the case among the oak species, the wood of which is used in great quantities for local mushroom production. Therefore the data regarding this habit need to be interpreted with caution.

The majority of the specialist species identified in the study are generally not used for urban paved sites in the CNE-region. In other parts of the world too, experience on the use of these species at paved sites within cities is still very limited except for Ailanthus altissima and Koelreuteria paniculata, which have proven long-standing adaptation to the harsh conditions at urban paved sites. In southern Europe, Ailanthus altissima is a widely used street tree for urban paved sites and Koelreuteria paniculata is used to some extent as well (Sæbø et al. 2005). Despite these experiences in regions of the world differing from the CNEregion, they can be seen as an indication of the potential usefulness of the remaining habitat specialists identified in this study.

\section{CONCLUSIONS}

The two important challenges in the planning and management of trees in urban streets and at other paved sites include the need for more knowledge and practical experience about site-adapted use of species, and the need for a greater variety of species and genera with natural adaptations for surviving and developing well at such sites. The problem for urban tree planners at present lies not in finding a great variety of species that are well adapted for the favorable growth conditions that often exist in urban woodlands and parklands, but in finding species that can withstand the harsh conditions at urban paved sites. In order to achieve a closer match between the study plots in the Qinling Mountains and paved sites of Copenhagen, new strategies such as increased planting pit size, including an allowance for stormwater infiltration in tree plantations, must be included when planning for trees at urban paved sites in the future.

This study in the Qinling Mountains identified 14 tree species (Group 2) for urban paved sites in the CNE-region. These can be considered a starting point in a possible selection process aimed at increasing the range of tree species and genera that are site-adapted for urban paved sites. However, aspects such as hardiness, health status, wood stability, allergy risks, propagation issues, establishment, and management problems must be tested before these new species are introduced into public places. Another important aspect is the possible invasiveness of these candidate species. The next stage of the process should be closed growing trials. Such trials should be started immediately, as tree selection is a long-term process, and the focus should be on promising, high-performing species instead of random testing.

Acknowledgments. Thanks to Zhang Wenhui and Kang Yongxiang at the Northwest Agriculture and Forestry University in Yangling, China, and Johan Slagstedt for supporting in the field work. We would also like to extend our gratitude to Kenneth Lorentzon for sharing his dendrology expertise and to Roland von Bothmer for fruitful comments on the manuscript.

\section{LITERATURE CITED}

Balok, C.A., and R., Hilaire. 2002. Drought responses among seven south-western landscape tree taxa. Journal of the American Society for Horticulture Science 127(2):211-218

Brady, N.C., and R. R., Weil. 2002. The nature and properties of soils Upper Saddle River, NJ: Prentice Hall. 960 pp.

Breckle S.W. 2002. Walter's vegetation of the world. 4th Edition. Springer. 527 pp.

Breda, N., R. Huc, A. Granier, and E. Dreyer. 2006. Temperate forest trees and stands under severe drought: a review of ecophysiological responses, adaptation processes and long-term consequences. Annals of Forest Science 63:625-644.

Bühler, O., P. Kristoffersen, and S.U. Larsen. 2007. Growth of street trees in Copenhagen with emphasis on the effect of different establishment concepts. Arboriculture and Urban Forestry 33:330-337.

Corcuera, L., J.J. Camarero, and E. Gil-Pelegrin. 2002. Functional groups in Quercus species derived from the analysis of pressurevolume curves. Trees: Structure and Function 16(7):465-472.

Craul, P.J. 1999. Urban Soil - Applications and Practices. John Wiley \& sons, Canada. $366 \mathrm{pp}$

David, T.S., M.O. Henriques, C. Kurz-Besson, J. Nunes, F. Valante, M. Vaz, J.S. Pereira, R. Siegwolf, M.M. Chaves, L.C. Gazarini, and J.S. David. 2007. Water-use strategies in two co-occurring Mediterranean evergreen oaks: surviving the summer drought. Tree Physiology 27:793-803.

DMI. 2009. Danish Meteorological Institute. <www.dmi.dk>

Ducatillion, C., and E. Dubois. 1997. Diversification des plantes ornimentales méditerranéennes: estimation des besoins qualitatifs des villes en arbres et arbustes (Diversification of ornamental mediterranean plants: assessment of the qualitative needs of cities concerning trees and shrubs), In: INRA (Ed.) La plante dans la ville. Angers. 139-149 pp. (French).

Duhme, F., and S. Pauleit. 2000. The dendrofloristic richness of SEEurope, a phenomenal treasure for urban plantings. Mitteilungen aus der Biologischen Bundesanstalt für Land- und Forstwirtschaft BerlinDahlem 370:23-39

Ehrlich, R., and B. Weinberg. 1970. An exact method for characterization of grain shape. Journal of Sedimentary Research - March 1970 40(1):205-212.

FAO. 2006. Guidelines for soil description. Food and agriculture organization of the united nation, Rome 2006. 98 pp.

Flint, H.L. 1985. Plants showing tolerance of urban stress. Journal of Environmental Horticulture 3(2):85-89.

Gale, M.R., and D.F. Grigal. 1987. Vertical root distribution of northern tree species in relation to successional status. Canadian Journal of Forest Research, 1987 17(8):829-834.

Grissino-Mayer, H.D. 2003. A manual and tutorial for the proper use of an increment borer. Tree-Ring Research 59(2):63-79. 
Gurevitch J., S.M. Scheiner, and G.A. Fox. 2002. The Ecology of Plants. Sinauer Associates, Inc. Publisher, Sunderland, Massachusetts U.S.A. 523 pp.

Kang, Y. 2009. Personal communication. May 25, 2009. Northwest A\&F University in Yangling, China.

Klute, A. 1986. Methods of soil analysis: Physical and Mineralogical methods. American Society of Agronomy, Agronomy Monographs 9(1), Madison, Wisconsin. 1188 pp.

Kozlowski, T.T., P.J. Kramer, and S.G. Pallardy. 1991. The physiological ecology of woody plants. Academic Press Inc. 454 pp.

Körner C., and E.M. Spehn. 2002. Mountain biodiversity: a global assessment. New York, NY: The Parthenon Publishing Group. 657 pp.

Lin, K., S. Guo, W. Zhang, and P. Liu. 2007. A new baseflow separation method based on analytical solutions of the Horton infiltration capacity curve. Hydrol. Process 21:1719-1736.

Liu, S. F., and J. Zhang. 2003. Biodiversity research and conservation in Fu Ping nature reserve. Shaanxi Technology Publishing House. 662 pp. (Chinese).

Meeus, J. 1991. Astronomical Algorithms. Willmann-Bell, Richmond. $477 \mathrm{pp}$.

Miller, R.H., and R.W. Miller. 1991. Planting survival of selected street tree taxa. Journal of Arboriculture 17(7):185-191.

Mossberg, B., and L. Stenberg. 2003. The New Nordic Flora. Wahlström and Widstrand. 928 pp. (Swedish).

Pauleit, S. 2003. Urban street tree plantings: Identifying the key requirements. Proceedings of the Institute of Civil Engineers-Municipal Engineers 156(1):43-50.

Pauleit, S., N. Jones, G. Garcis-Martin, J.L. Garcia-Valdecantos, L.M. Riviere, L. Vidal-Beaudet, M. Bodson, and T.B. Randrup. 2002. Tree establishment practise in towns and cities - Result from a European survey. Urban Forestry \& Urban Greening 1(2):83-96.

P90. 2004. Publication P90 - Dimension public sewer pipes. Svenskt Vatten AB. Ljungföretagen 36 pp. (Swedish).

Rabinowitz, D. 1981. Seven forms of rarity. In: H. Synge (Ed.). The Biological Aspects of Rare Plant Conservation. John Wiley, Chicester, UK. 205-217 pp.

Raupp, M.J., M.J. Cumming, and E.C. Raupp. 2006. Street tree diversity in eastern North America and its potential for tree loss to exotic borers. Arboriculture \& Urban Forestry 32(6):297-304.

Richards, N.A. 1983. Diversity and stability in a street tree population. Urban Ecology 7:159-171.

Roloff, A., S. Korn, and S. Gillner. 2009. The climate-species-matrix to select tree species for urban habitats considering climate change. Urban Forestry and Urban Greening 8:295-308.

Sæbø, A., B. Zelimir, C. Ducatillion, A. Hatzistathis, T. Lagerström, J. Supuka, J.L. Garcis-Valdecantos, F. Rego, and J. Slycken. 2005. The selection of plant materials for street trees, park trees and urban woodlands In: C.C. Konijnendijk, K. Nilsson, T.B. Randrup, and J. Schipperijn (Eds.). Urban Forests and Trees. Springer. 257-280 pp.

Santamour, F.S., Jr. 1990. Trees for urban planting: Diversity, uniformity and common sense. Proceedings of the 7th Conference of the Metropolitan Tree Improvement Alliance 7:57-65.

Sims, J.R., and V.A. Haby. 1971. Simplified colorimetric determination of soil organic matter. Soil Science 112:137-141.

Sieghardt, M., E. Mursch-Radlgruber, E. Paoletti, E. Couenberg, A. Dimitrakopoulus, F. Rego, A. Hatzistatthis, and T. Randrup. 2005. The abiotic urban environment: Impact of urban growing conditions on urban vegetation. In: C.C. Konijnendijk, K. Nilsson, T.B. Randrup, and J. Schipperijn (Eds.). Urban Forests and Trees. Springer. 281-323 pp.
Sperry, J.S., F.R. Adler, G.S. Campbell, and J.P. Comstock. 1998. Limitation of plant water use by rhizosphere and xylem conductance: results from a model. Plant, Cell and Environment 21:347-359.

Spurr, S.H., and B.V. Barnes. 1980. Forest Ecology. John Wiley and Son, Inc. New York. 681 pp.

Sun, W.Q. 1992. Quantifying species diversity of streetside trees in our cities. Journal of Arboriculture 18(2):91-93.

Takhtajan, A. 1986. Floristic of the world. Univ. of California Press. 522 pp.

Tan, K.H. 2005. Soil sampling, preparation and analysis. 2nd edition. CRC Press. 623 pp.

Tang, Z., and Fang, J. 2006. Temperature variation along the northern and southern slopes of Mt. Taibai, China. Agricultural and Forest Meteorology 139:200-207.

Tang Z., Z. Wang, C. Zheng, and J. Fang. 2006. Biodiversity in China's mountains. Frontiers in Ecology and the Environment 4(7):347-352.

Tello, M-L., M. Tomalak, R. Siwecki, J. Gaper, E. Motta, and E. MateoSagasta. 2005. Biotic urban growing condition - threats, pests and diseases. In: C.C. Konijnendijk, K. Nilsson, T.B. Randrup, and J. Schipperijn (Eds.). Urban Forests and Trees. Springer. 325-365 pp.

Thornthwaite, C.W. 1948 - An approach toward rational classification on climate. Geographical Review 38(1):55-94.

U.S. EPA. 2009. U.S. Environmental Protection Agency. <http://www. epa.gov/heatislands/>

Ware, G.H. 1994. Ecological bases for selecting urban trees. Journal of Arboriculture 20(2):98-103.

West, A.G., K.R. Hultine, T.L. Jackson, and J.R. Ehleringer. 2007. Differential summer water use by Pinus edulis and Juniperus osteosperma reflects contrasting hydraulic characteristics. Tree Physiology 27:1711-1720.

Whitlow, T.H., N.L. and Bassuk. 1987. Trees in difficult sites. Journal of Arboriculture 13(1):10-17.

Ying, T-S., and D.E. Boufford. 1998. Phytogeography of the Qinling Mountains and a comparison with the flora and vegetation of Japan. In: D.E. Boufford and H. Ohba (Eds.). Sino-Japanese flora it's characteristics and diversification. The University Museum, The University of Tokyo, Bulletin No. 37. pp. 1-29.

Henrik Sjöman (corresponding author) Swedish University of Agriculture Science

Landscape planning, Horticulture and Agricultural Science

Landscape Management, Design, and Construction

Alnarp, Sweden

Anders Busse Nielsen

Swedish University of Agriculture Science

Landscape planning, Horticulture and Agricultural Science

Landscape Management, Design, and Construction

Alnarp, Sweden

\section{Stephan Pauleit}

Technische Universitaet Muenchen

Strategic Landscape Planning and Management

Munich, Germany

Mats Olsson

Swedish University of Agriculture Science

Natural Resources and Agriculture Science

Department of Soil and Environment

Uppsala, Sweden 
Résumé. Les arbres au sein d'environnements urbains pavés sont fortement exposés à la chaleur, au faible taux d'humidité de l'air, aux périodes critiques de stress hydrique, au contenu élevé du sol en calcaire et au pH élevé, à un volume limité de sol, aux polluants et au sel de déglaçage. Combiné au défi des changements climatiques et aux infestations par les insectes et les maladies, cela constitue alors un argument de poids pour employer une plus large variété d'arbres, incluant des espèces tolérantes aux stress dans des zones urbaines pavées. Des recherches poussées sur le terrain ont été menées dans la région des montagnes Qinling en Chine afin de trouver des espèces adaptées pour les conditions urbaines pavées dans les régions nordiques d'Europe Centrale et les régions adjacentes de l'Europe septentrionale, là où les arbres sont exposés à des conditions saisonnières sèches et difficiles. L'étude a identifié des habitats dans la région montagneuse du Qinling qui sont similaires aux sites environnementaux pavés de même qu'elle a analysé la croissance et la performance de différentes espèces d'arbres dans ces habitats. Un total de 25 espèces d'arbres regroupées au sein de 21 genres ont été découvertes parmi lesquelles 14 espèces ont été identifiées comme des colonisateurs spécialisés des pentes méridionales chaudes et sèches dont les conditions de site sont similaires à celles des environnements pavés de l'Europe septentrionale.

Zusammenfassung. Bäume in zugepflasterten urbanen Standorten sind extremen Bedingungen, wie Hitze, geringe Luftfeuchte, Perioden mit kritischer Wasserversorgung, hohem Lehmanteil und Boden-pH, begrenztem Bodenvolumen, Verschmutzungen und Streusalzen unterworfen. In Verbindung mit den Klimaveränderungen und Befall durch Krankheiten und Insekten führt das zu wichtigen und anhaltenden Argumenten, eine größere Auswahl von Bäumen zu verwenden, einschließlich stress-resistenten Arten an gepflasterten Standorten. In den QinlingBergen, einer Region in China, wurden ausgedehnte Feldstudien durch- geführt, um Baumarten für urbane gepflasterte Räume im nördlichen Zentraleuropa und in den angrenzenden milderen Teilen von Nordeuropa (CNE-Region), wo Bäume saisonal trockenen, harten Klimabedingungen ausgesetzt sind. Diese Studie identifiziert Habitate in der QinlingBergregion, die ähnlich den gepflasterten Standorten sind und analysiert das Wachstum und Performance von verschiedenen Baumarten in diesen Habitaten. Insgesamt wurden 25 Baumarten aus 21 Familien gefunden, wovon 14 Arten wiederum identifiziert wurden als besonders geeignet für warme, nach Süden ausgerichtete Hänge, wo die Standortbedigungen ähnlich denen in gepflasterten Umgebungen in den CNE-Regionen waren.

Resumen. Los árboles en ambientes pavimentados están altamente expuestos al calor, baja humedad del aire, períodos críticos de estrés hídrico, alto contenido de cal y $\mathrm{pH}$ del suelo, volumen limitado de suelo, contaminantes, y sales de deshielo. Combinado con los desafíos de cambio climático y la amenaza de infestaciones de plagas y enfermedades, esto da considerables y persistentes argumentos para usar un rango más variado de árboles, incluyendo especies tolerantes al estrés, en sitios pavimentados. Se llevó a cabo un extenso trabajo de campo en las Montañas Qinling, China, en una investigación para especies de árboles apropiados para sitios urbanos pavimentados en las partes noreste de $\mathrm{Eu}-$ ropa Central, donde las especies de árboles están expuestas a condiciones estacionales crudas y de sequía. El estudio identificó hábitats en rangos de las Montañas Qinling que son similares a los sitios en ambientes pavimentados, y analizaron el crecimiento y comportamiento de diferentes especies de árboles en esos hábitats. Un total de 25 especies de árboles representado 21 géneros fueron encontrados, de los cuales 14 especies fueron identificados como colonizadores especialistas de pendientes calientes y secas, donde las condiciones del sitio son similares a las de los ambientes pavimentados en la región central de Europa. 